\title{
LATE LAYING BY A BROWN-HEADED COWBIRD, IN AN AMERICAN GOLDFINCH NEST
}

Spencer G. Sealy

Department of Biological Sciences

University of Manitoba

Winnipeg, MB R3T 2N2

Spencer.Sealy@umanitoba.ca

Infrequent parasitism on the American Goldfinch (Spinus tristis) by the Brown-headed Cowbird (Molothrus ater) has usually been explained by the potential host's latenesting schedule. ${ }^{1,2}$ At parasitized goldfinch nests, cowbird chicks generally do not survive the nestling period due to incompatibility of the diet of the host (regurgitated seeds) and parasite (insects). ${ }^{3,4}$ The breeding seasons of these species overlap only to a small extent, such that by the time the last cowbird eggs are laid, goldfinches have only begun to initiate clutches. The relationship between the two species in this rather short period of overlap has been studied most extensively in southern Ontario. 2,4 of 802 goldfinch nests, 47 (5.7\%) were parasitized, but only 13 eggs hatched, and no cowbirds fledged. The author stated, "...although the cowbird gained little advantage from the association, its parasitism largely offset the advantages of early nesting by the adult goldfinches. The goldfinch has not developed any apparent defense against cowbird parasitism, but those individuals that nested in manmade habitats were largely free of its influence. " 2 In this note, I report cowbird parasitism on an American Goldfinch nest near Battleford, Saskatchewan. The late date of laying is confirmed by comparison with cowbird laying dates recorded at Delta Marsh, Manitoba.

Listed as a cowbird host in
Saskatchewan ${ }^{5,6}$, the low frequency of parasitism on American Goldfinch is typical of most other localities where nests of this species have been studied. ${ }^{1,2,7}$ Of 33 goldfinch nests reported from Saskatchewan to the Prairie Nest Records Scheme (PNRS), three (9.1\%) were parasitized by cowbirds whose eggs were first recorded on 19 July 1967 at Yellow Creek (PNRS card \#25114); on 27 June 1969 at Lady Lake (PNRS \#25123); and on 18 June 1974 at Hagen (PNRS \#25128). As these nests were not inspected daily, exact laying dates of goldfinches or cowbirds were not determined. Fates of the single cowbird eggs in these nests were: (1) buried under a new nest lining (Hagen); (2) disappeared at least nine days into incubation (Lady Lake); and goldfinch and cowbird nestlings disappeared eight days after hatching, apparently depredated (Yellow Creek).

To this total, from field notes made at the time of the original observations, I report cowbird parasitism on a goldfinch nest located near Prongua, Saskatchewan (52 $\left.{ }^{\circ} 74^{\prime} \mathrm{N}, 108^{\circ} 55^{\prime} \mathrm{W}\right)$, about $17 \mathrm{~km}$ south of Battleford. On 10 July 1980, a nest about $2 \mathrm{~m}$ high in a Trembling Aspen (Populus tremuloides) contained four goldfinch eggs plus one cowbird egg. Two days later, the nest contained a fifth and final goldfinch egg, assuming the cowbird did not remove a goldfinch egg around the time of parasitism ${ }^{2,9}$, as six-egg goldfinch clutches have been recorded in Saskatchewan. 8,10 The cowbird's egg probably was laid on 6 or 7 July 1980, as goldfinch nests are normally parasitized the morning before or on the day the first goldfinch egg was laid. ${ }^{4}$

The span of laying dates over the cowbird's breeding season has not been determined in Saskatchewan, but at Delta Marsh, Manitoba, most cowbirds cease laying by the time their primary hosts (Yellow Warbler [Setophaga petechia], Red-winged Blackbird [Agelaius phoeniceus], and Song Sparrow [Melospiza melodia]) have ceased laying, in late June or during the first few days of July. ${ }^{11-13}$ This was confirmed by superimposing cowbird laying dates on clutchinitiation dates of the Yellow Warbler, based initially on data collected from 1974 to $1976 .{ }^{11}$ The last warbler clutch was initiated on 2 July 1974 (last cowbird egg laid 2 July), on 7 July 1975 (9 July, in 3-egg clutch), and on 6 July 1976 (23 June 1976). Data collected on Yellow Warblers between 1994 and 1998 revealed last cowbird eggs were laid on 28 or 29 June in four of the years, but on 9 July in $1994 .^{12}$

Exceptionally late cowbird laying dates were recorded at Delta Marsh, at nests of two species: Least Flycatcher (Empidonax minimus) on 12 July 1980 and Cedar Waxwing (Bombycilla cedrorum) on 13 July 1996. Even later, a cowbird fledgling being fed by a Common Yellowthroat (Geothlyis trichas) on 20 August $1992^{13}$ probably hatched no earlier than 15 July. These observations revealed some adult female cowbirds remained through the middle of July after most other adults and juveniles have left the area $^{14,15}$, apparently having migrated. None of the $\sim 1,100$ cowbirds banded at Delta Marsh ${ }^{16}$ was encountered during southward migration or on the wintering 
ground, but an adult male banded at Muscow, Saskatchewan, on 13 June 1929, and found dead in New Mexico about two weeks later, provides anecdotal support for early departure and longdistance southward migration from Saskatchewan. ${ }^{6}$

Female cowbirds at the northern edge of their range that remain at the breeding sites well into July have fewer opportunities for parasitism as most individuals of the primary host species have ceased laying 11,12, leaving available nests of mostly poor hosts. Factors that influence decisions of cowbirds leading up to termination of laying and southward migration are important avenues for further study.

\section{Acknowlegements}

I am indebted to Glenn C. Sutter, Royal Saskatchewan Museum, for providing data for American Goldfinch nests contained in the files of the PNRS. A big thank you to the individuals who took time to submit nest cards to the PNRS, thus contributing to an important source of information. Paul Goossen's and Bonnie Woolfenden's inspections of nests provided data on the seasonal pattern of cowbird parasitism on the primary host species at Delta Marsh, in the 1970s and 1990s, respectively. Gloria Biermann Pohajdak and Glen McMaster discovered the parasitized nests of Least Flycatcher and Cedar Waxwing, respectively. I thank an anonymous reviewer for constructive comments on the manuscript.

1. Friedmann H, Kiff LF (1985) The parasitic cowbirds and their hosts. Proceedings of the Western Foundation of Vertebrate Zoology 2:226-302.

2. Middleton ALA (1977) Effect of cowbird parasitism on American Goldfinch nesting. Auk 94:304-307.

3. Friedmann H, Kiff LF, Rothstein SI (1977)

A further contribution to knowledge of the host relations of the parasitic cowbirds. Smithsonian Contributions to Zoology, Number 235.

4. Middleton ALA (1991) Failure of Brownheaded Cowbird parasitism of the American Goldfinch. Journal of Field Ornithology 62:200-203

5. Friedmann $\mathrm{H}$ (1963) Host relations of the parasitic cowbirds. United Sates National Museum Bulletin, Number 233.

6. Sealy SG (2019) Brown-headed Cowbird. Pages 636-638 in Birds of Saskatchewan (Smith AR, Houston CS, Roy JF, editors). Nature Saskatchewan, Regina.

7. Peck GK, James RD (1987) Breeding birds of Ontario: Nidiology and distribution, Volume 2: Passerines. Royal Ontario Museum, Toronto.

8. Kratzig GP, Houston CS (2019) American Goldfinch. Pages 663-665 in Birds of Saskatchewan (Smith AR, Houston CS, Roy JF, editors). Nature Saskatchewan, Regina.

9. Sealy SG (1992) Removal of Yellow Warbler eggs in association with cowbird parasitism. Condor 94:40-54.

10. Hooper DF (1992) Birds of East-Central Saskatchewan, Kelvington to Kelsey Trail. Saskatchewan Natural History Society Special Publication, Number 18.

11. Goossen JP (1978) Breeding biology and reproductive success of the Yellow Warbler on the Delta Beach Ridge, Manitoba. M.Sc. thesis, University of Manitoba, Winnipeg.

12. Woolfenden BE, McLaren CM, Sealy SG, Gibbs HL (2004) Community-level patterns of parasitism: Use of three common host species by a brood parasitic bird, the Brownheaded Cowbird. Écoscience 11:238-248.

13. Sealy SG (2016) Additional observations of putative host species feeding only cowbird fledglings. Blue Jay 74(3):28-31.

14. Woolfenden BE, Gibbs HL, Sealy SG (2001) Demography of Brown-headed Cowbirds at Delta Marsh, Manitoba. Auk 118:156-166.

15. Holland GE, Taylor P (2003) Brownheaded Cowbird. Pages 382-383 in The Birds of Manitoba, Manitoba Naturalists Society, Winnipeg.

16. Sealy SG (2019) Report on birds banded in the dune-ridge forest, Delta Marsh, Manitoba, 1973-1988. Blue Jay 77(1):42-47
POETRY

\section{Cloudy With Sunny Breaks}

Four or five Ravens

blacken before a flock

of Snow Geese streaming

home from the south.

Reflecting the sunlight

they are silver and blue in their barking flight

upon brooding grey skies.

\author{
George Grassick \\ Box 205 \\ Lumsden, SK \\ SOG 3 CO \\ ggrassick@sasktel.net
}

